\title{
Polythionate degradation by tetrathionate hydrolase of Thiobacillus ferrooxidans
}

\author{
Govardus A. H. de Jong, Wim Hazeu, Piet Bos and J. Gijs Kuenen
}

Author for correspondence: J. Gijs Kuenen. Tel: +31 152 785308. Fax: +31 152782355.

Department of Microbiology and Enzymology, Delft University of Technology, Julianalaan 67,2628 BC

Delft, The Netherlands

\begin{abstract}
Cell-free extracts of Thiobacillus ferrooxidans grown with thiosulfate as energy source and prepared at high ammonium sulfate concentrations and at low pH are capable of polythionate hydrolysis. The enzyme responsible for the hydrolysis of tetrathionate $\left(\mathrm{S}_{4} \mathrm{O}_{6}^{2-}\right)$ and pentathionate $\left(\mathrm{S}_{5} \mathrm{O}_{6}^{2-}\right)$ was purified to homogeneity. Enzyme activity during the purification procedure was based on a continuous spectrophotometric method that detects soluble intermediates that absorb in the UV region. The end products of hydrolysis of both polythionates by the pure enzyme were thiosulfate, sulfur and sulfate. The purified enzyme has a pH optimum of around 4 and a temperature optimum of $65^{\circ} \mathrm{C}$. The activity is strongly influenced by the presence of sulfate ions. The purified enzyme is a dimer with two identical subunits of molecular mass $52 \mathrm{kDa}$. During purification of tetrathionate hydrolase, fractions able to hydrolyse trithionate and tetrathionate were separated, indicating that the two substrates are hydrolysed by different enzymes.
\end{abstract}

Keywords: Thiobacillus ferrooxidans, polythionates, tetrathionate hydrolase, acidophilic bacteria, sulfur metabolism

\section{INTRODUCTION}

During the dissimilation of thiosulfate by sulfuroxidizing bacteria, the intermediary production of polythionates has frequently been reported for neutrophilic and acidophilic organisms. Starkey (1935), Trudinger (1964a, 1965), Vishniac (1952) and Meulenberg et al. (1992a) mentioned the production of tetrathionate from thiosulfate by Thiobacillus species. Trithionate also seems to be an intermediate in thiosulfate metabolism with Thiobacillus neapolitanus (Sklodowska, 1988; Trudinger, 1964b), Thiobacillus thioparus (Vishniac, 1952), Thiobacillus strain C (Kelly \& Syrett, 1966) and Thiobacillus tepidarius (Lu \& Kelly, 1988). During thiosulfate and tetrathionate degradation by acidophilic Thiobacillus species, trithionate, pentathionate and sulfur were detected (Parker \& Prisk, 1953; London \& Rittenberg, 1964; Sinha \& Walden, 1966; Okuzumi \& Kita, 1965; Landesman et al., 1966).

Despite numerous investigations, the production and metabolism of polythionates is not completely understood. Okuzumi $(1965,1966)$ reported dismutation of tetrathionate by cells and cell-free extracts of Thiobacillus thiooxidans, resulting in the production of trithionate and pentathionate. The process was sulfatedependent and proceeded at $\mathrm{pH} 3 \cdot 0 . T$. neapolitanus strain $\mathrm{X}$ degraded tetrathionate and trithionate an- aerobically. Variable concentrations of thiosulfate, sulfur and minor amounts of trithionate and pentathionate were formed from tetrathionate, while trithionate metabolism resulted in thiosulfate and sulfate production (Trudinger, 1964b, c).

In studies with Thiobacillus ferrooxidans, the production of tetrathionate from thiosulfate was also observed (Pronk et al., 1990). The subsequent tetrathionate degradation was found to be sulfate-dependent, as has also been reported for T. acidophilus (Meulenberg et al., 1992a) and for trithionate hydrolysis by T. tepidarius (Lu \& Kelly, 1988), and resulted in intermediate 'hydrophilic sulfur' production (Hazeu et al., 1988).

A working hypothesis for the mechanism of sulfur and polythionate production from tetrathionate was developed by Steudel et al. (1987). The key reaction in this model is the (enzymic) hydrolysis of tetrathionate to sulfate and sulfane-monosulfonic acid:

$\mathrm{S}_{4} \mathrm{O}_{6}^{2-}+\mathrm{H}_{2} \mathrm{O} \rightarrow \mathrm{HS}_{2} \mathrm{SO}_{3}^{-}+\mathrm{HSO}_{4}^{-}$

Sulfane-monosulfonic acid is postulated to play an essential role in a chemical process of sulfur chain elongation, ultimately resulting in the production of sulfur as $\mathrm{S}_{8}$ and sulfite (Steudel et al., 1987, 1988; Hazeu et al., 1988; Steudel, 1989). At present there is no experimental evidence for this mechanism. Enzymic 
hydrolysis of tetrathionate to thiosulfate, sulfur and sulfate has been shown in T. acidophilus (Meulenberg et al., 1993a):

$$
\mathrm{S}_{4} \mathrm{O}_{6}^{2-}+\mathrm{H}_{2} \mathrm{O} \rightarrow \mathrm{S}+\mathrm{S}_{2} \mathrm{O}_{3}^{2-}+\mathrm{SO}_{4}^{2-}+2 \mathrm{H}^{+}
$$

The enzyme for this reaction was partially purified and shown to be different from the T. acidophilus enzyme that converts trithionate to thiosulfate (Meulenberg $e t$ al., 1992b). Tetrathionate hydrolase activity was shown by measuring the production of protons [see reaction (2)].

T. acidophilus is a facultative chemolithotrophic bacterium frequently observed as a satellite population of $T$. ferrooxidans cultures. The latter organism is an obligate chemolithotrophic sulfur- and iron-oxidizing bacterium active in the bacterial leaching of sulfidic ores. As T. ferrooxidans, in spite of its name, is not related to T. acidophilus (Lane et al., 1992), it is of great interest to identify and purify the tetrathionate hydrolase from T. ferrooxidans. However, the lack of a suitable activity assay has complicated the search for this enzyme.

This paper describes the hydrolytic degradation of polythionates by cell-free extracts of $T$. ferrooxidans, with emphasis on the development of a continuous activity assay, and the purification and partial characterization of tetrathionate hydrolase.

\section{METHODS}

Organism and growth conditions. Thiobacillus ferrooxidans ATCC 19859 (LMD 81.68) was grown in a chemostat culture on thiosulfate $(30 \mathrm{mM})$ at a dilution rate of $0.02 \mathrm{~h}^{-1}$ as previously reported (Hazeu et al., 1986).

Analytical procedures. Tetrathionate, pentathionate and thiosulfate concentrations were determined by cyanolysis (Kelly $e t$ al., 1969), modified for measurements at high ammonium sulfate concentrations (Meulenberg et al., 1992b). Precipitated sulfur was extracted overnight in acetone and analysed by cyanolysis (Hazeu et al., 1988).

Development of continuous enzyme assays. Different methods for measuring polythionate hydrolysis include measurement of the product of trithionate hydrolysis, thiosulfate, using HPLC or cyanolysis. A disadvantage of these methods is their discontinuity. In addition, the cyanolysis reaction is not specific for one sulfur compound (Kelly et al., 1969). Therefore continuous spectrophotometric tests were developed for both trithionate and tetrathionate. As reported by Meulenberg et al. (1992b), the conversion of trithionate into thiosulfate can be followed at $220 \mathrm{~nm}$ as thiosulfate has a maximum absorbance at this wavelength, while trithionate has its maximum at $205 \mathrm{~nm}$.

For analysis of tetrathionate conversion, a more empirical test was developed. As pointed out in the Introduction, hydrolysis of tetrathionate, according to reaction (1), might initiate chemical or enzymic reactions, ultimately resulting in a mixture of sulfur compounds as well as proton production. In the region between 250 and $430 \mathrm{~nm}$, enzymic hydrolysis of tetrathionate resulted in increased light absorbance. This increase may be explained by assuming the production of intermediates with longer sulfur chains which also absorb at these wavelengths, although their maximum absorbance may be at higher wavelengths than tetrathionate (Baer \& Carmack, 1949). As a compromise between sensitivity and practical applicability, the increase in $A_{290}$ was chosen to monitor the hydrolysis of tetrathionate. The production of 'hydrophilic sulfur' as one of the products of tetrathionate hydrolysis could conveniently be followed at $430 \mathrm{~nm}$. Control experiments were carried out with extract inactivated by boiling for $5 \mathrm{~min}$. Anaerobic tests were carried out in stoppered cuvettes after flushing with nitrogen gas for $5 \mathrm{~min}$. Activity of tetrathionate hydrolysis was expressed as $\Delta A_{280} \min ^{-1}$.

Discontinuous enzyme assays. Tetrathionate $(1 \mathrm{mM})$ was added to $2 \mathrm{ml}$ of $1 \mathrm{M}$ ammonium sulfate buffer ( $\mathrm{pH} 3$ ) in a thermostat-controlled $\left(30^{\circ} \mathrm{C}\right)$ reaction chamber. After the addition of protein, $0.2 \mathrm{ml}$ samples were taken at desired time intervals, immediately mixed with $5 \mu \mathrm{l} 1 \mathrm{M} \mathrm{NaOH}$ and put on ice to stop the reaction. Tetrathionate, thiosulfate and sulfur concentrations were determined by cyanolysis. The specific activity for calculation of enzyme activities after each separation step was expressed as $\mathrm{U}$ (mg protein $)^{-1}$. One unit (U) is defined as the amount of enzyme required for the hydrolysis of $1 \mu \mathrm{mol}$ tetrathionate $\mathrm{min}^{-1}$.

Enzyme purification procedure. Bacterial cells $(2 \cdot 4 \mathrm{~g}$ wet wt) from a chemostat culture of $T$. ferrooxidans were collected at $4^{\circ} \mathrm{C}$ and centrifuged $(10 \mathrm{~min}$ at $12000 \mathrm{~g})$. The biomass was washed and resuspended in $5 \mathrm{ml}$ of a buffer containing $25 \mathrm{mM}$ potassium phosphate and $2 \mathrm{M}$ ammonium sulfate $(\mathrm{pH} 3)$ and disrupted in a French pressure cell at $110 \mathrm{MPa}$. The suspension was centrifuged for $20 \mathrm{~min}$ at $48000 \mathrm{~g}$ to remove most of the cell debris. The supernatant was centrifuged for $120 \mathrm{~min}$ at $100000 \mathrm{~g}$. The resulting clear supernatant $(4.75 \mathrm{ml})$ was applied to a phenyl-Sepharose column $(5 \times 3 \mathrm{~cm})$ that had been equilibrated in buffer containing $25 \mathrm{mM}$ potassium phosphate and $2 \mathrm{M}$ ammonium sulfate $(\mathrm{pH} 3)$. A gradient from 2 to $0 \mathrm{M}$ ammonium sulfate in $25 \mathrm{mM}$ potassium phosphate $(\mathrm{pH} 3)$ was applied at a flow rate of $4 \mathrm{ml} \mathrm{min}^{-1}$ for $90 \mathrm{~min}$. Pooled active fractions were concentrated with Centriprep-30 (Amicon) and further purified on a Pharmacia Superdex 200 column equilibrated with buffer containing $25 \mathrm{mM}$ potassium phosphate and $1 \mathrm{M}$ ammonium sulfate $(\mathrm{pH}$ 3) at a flow rate of $0.5 \mathrm{ml} \mathrm{min}^{-1}$. The eluted active fractions were stored at $-80^{\circ} \mathrm{C}$.

Molecular mass determination. Native molecular mass was determined by gel filtration on a Pharmacia Superdex 200 column equilibrated with buffer containing $25 \mathrm{mM}$ potassium phosphate and $1 \mathrm{M}$ ammonium sulfate $(\mathrm{pH} 3)$ at a flow rate of

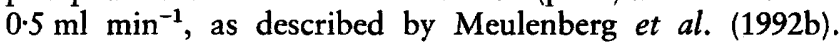
Subunit molecular masses were determined under denaturing conditions by SDS-PAGE according to Laemmli (1970) using a $10 \%$ polyacrylamide gel and Mini Protean equipment (Bio$\mathrm{Rad})$. Enzyme samples were denatured by incubation for $5 \mathrm{~min}$ at $100^{\circ} \mathrm{C}$ in $2 \%$ SDS and $10 \% \beta$-mercaptoethanol. A low molecular mass calibration kit (Pharmacia) was used to derive the molecular masses. Gels were stained for protein with Coomassie Brilliant Blue G250.

Spectroscopy. UV/visible absorption spectra were measured on a Hewlett Packard 8524A diode array spectrometer. Calculation of the specific absorption coefficient of the purified enzyme was performed using the ratio between $A_{205}$ and $A_{280}$ as described by Van Iersel et al. (1985).

Determination of $\mathrm{pH}$ optimum, optimum temperature and kinetic constants. The pH optimum of tetrathionate hydrolase was determined with the standard assay buffer using the 
continuous activity assay at $290 \mathrm{~nm}$. The $\mathrm{pH}$ was varied between 1.5 and 7 by adjusting the $\mathrm{pH}$ of the assay buffer with either $1 \mathrm{M} \mathrm{H}_{2} \mathrm{SO}_{4}$ or $1 \mathrm{M} \mathrm{NaOH}$. The temperature optimum was studied with the standard assay buffer using the continuous activity assay at $290 \mathrm{~nm}$. The temperature was varied between 15 and $75^{\circ} \mathrm{C}$ and the actual temperature was measured in the cuvette. The kinetic parameters were determined at $\mathrm{pH} 3$ and $30^{\circ} \mathrm{C}$ under standard conditions.

Chemicals. Sodium pentathionate and sodium hexathionate were kindly supplied by Prof. Dr R. Steudel (Technical University, Berlin, Germany). Trithionate was prepared as described by Wood \& Kelly (1986). All other chemicals were analytical grade and obtained from commercial sources.

\section{RESULTS}

\section{Purification and physical properties}

Cell-free extract of $T$. ferrooxidans prepared in high concentrations of ammonium sulfate $(1 \mathrm{M})$ and at low $\mathrm{pH} \quad(\mathrm{pH} 3)$ hydrolysed trithionate, tetrathionate $\left.\left[0.7 \mu \mathrm{mol} \mathrm{min}{ }^{-1} \text { (mg protein }\right)^{-1}\right]$ and thiosulfate. Extracts prepared at neutral $\mathrm{pH}$ in the presence of high ammonium sulfate concentrations $(1 \mathrm{M})$ or at low $\mathrm{pH}$ (pH 3) without salt showed a decrease in the specific activity of tetrathionate hydrolase of $93 \%$ and $70 \%$, respectively, compared to the initial conditions. Activities were measured immediately after preparation of the cell-free extract. The purification scheme for the isolation of the tetrathionate hydrolase is given in Table 1. The low $\mathrm{pH}$ and high salt concentration used for preparation of the cell-free extract caused denaturation of most proteins, leading to a supernatant after centrifuging with a low protein concentration, $50 \%$ of which appeared to be tetrathionate hydrolase. The specific activity of the different fractions was calculated from the quantitative discontinuous (cyanolytic) assay. Although the mechanism of tetrathionate hydrolysis is still unknown, the initial hydrolysis step was found to result in an immediate increase in absorbance in the UV region. Sulfur production could be observed after a short lag phase (Fig. 1). This change in spectrum was used as an empirical continuous method to monitor the activity of numerous protein fractions during the purification procedure.

Active fractions obtained after gel filtration on Superdex 200 appeared to be homogeneous, as judged by peak purity criteria as well as by SDS-PAGE. Determination

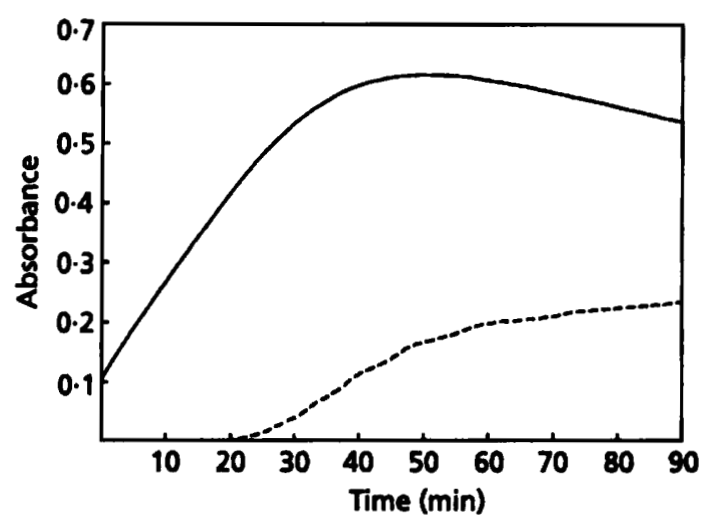

Fig. 1. Increase in $A_{290}(-)$ and $A_{430}(--)$ after addition of $1 \mathrm{mM}$ tetrathionate to cell-free extracts of $T$. ferrooxidans suspended in $1 \mathrm{M}$ ammonium sulfate ( $\mathrm{pH} 3)$. The final protein concentration was $0.1 \mathrm{mg} \mathrm{ml}^{-1}$.

of native molecular mass by gel filtration yielded a value of $105 \mathrm{kDa}$; subunit mass determination by SDS-PAGE yielded a value of $52 \mathrm{kDa}$. The absorbance spectrum of the tetrathionate hydrolase is characterized by a single peak at $280 \mathrm{~nm}$ and no absorbance above $300 \mathrm{~nm}$ (data not shown).

The trithionate-hydrolysing fraction was completely separated from the tetrathionate-hydrolysing fraction obtained from the phenyl-Sepharose column. The total amount of trithionate hydrolase protein appeared to be very low, but easily detectable due to its high specific activity.

\section{Catalytic properties of the tetrathionate hydrolase}

Incubation of the purified tetrathionate hydrolase with tetrathionate led to the stoichiometric formation of thiosulfate and sulfur (Fig. 2). The reaction proceeded at the same rate under both aerobic and anaerobic conditions. From the reaction stoichiometry [as shown in reaction (2)] it can be seen that one equivalent of sulfate should be produced. However, because of the sulfate requirement in the assay buffer, sulfate production could not be measured. The products initially formed from the hydrolysis of tetrathionate and pentathionate by the same enzyme differ in their UV/visible absorbance (Fig.

Table 1. Purification of tetrathionate hydrolase from thiosulfate-grown $T$. ferrooxidans

\begin{tabular}{|lcccc|}
\hline Purification step & $\begin{array}{c}\text { Total protein } \\
(\mathbf{m g})\end{array}$ & $\begin{array}{c}\text { Specific activity [U (mg } \\
\left.\text { protein) })^{-1}\right]^{*}\end{array}$ & Yield (\%) & $\begin{array}{c}\text { Purification } \\
\text { factor }\end{array}$ \\
\hline Cell-free extract & 41 & $0 \cdot 7$ & 100 & 1 \\
Phenyl-Sepharose & 20 & $1 \cdot 3$ & 85 & 2 \\
Gel filtration & 18 & $1 \cdot 4$ & 80 & $2 \cdot 1$ \\
\hline
\end{tabular}

* One unit $(\mathrm{U})$ is defined as the amount of enzyme required for the hydrolysis of $1 \mu \mathrm{mol}$ tetrathionate $\min ^{-1}$. 


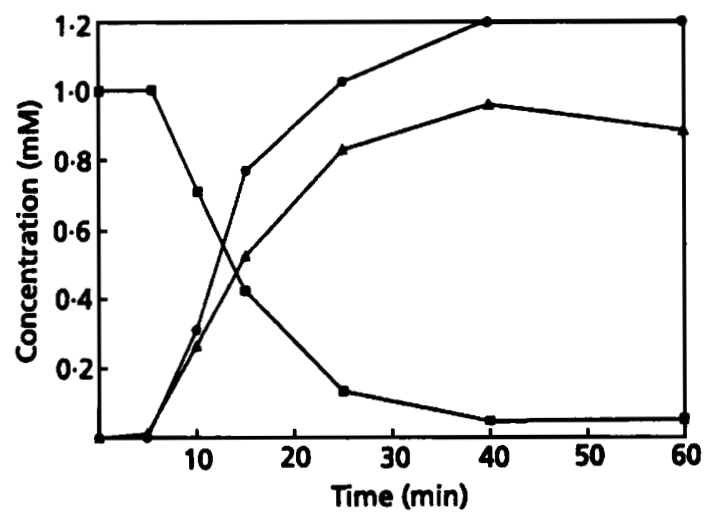

Fig. 2. The stoichiometry of tetrathionate hydrolysis. Purified protein $\left(0.04 \mathrm{mg} \mathrm{m}^{-1}\right)$ was incubated in $1.7 \mathrm{M}$ ammonium sulfate in a reaction chamber at $30^{\circ} \mathrm{C}$. After addition of $1 \mathrm{mM}$ tetrathionate, $2.5 \mathrm{ml}$ samples were taken at appropriate time intervals, immediately mixed with $40 \mu \mathrm{l} 1 \mathrm{M} \mathrm{KOH}$ and centrifuged. The concentrations of tetrathionate and thiosulfate in the supernatant were detected by cyanolysis. The pellet was washed with $2 \mathrm{M}$ ammonium sulfate $(\mathrm{pH} 3)$, recentrifuged and its sulfur content was determined after extraction with acetone. $\square$, tetrathionate; $\boldsymbol{O}$, thiosulfate; $\Delta$, sulfur.

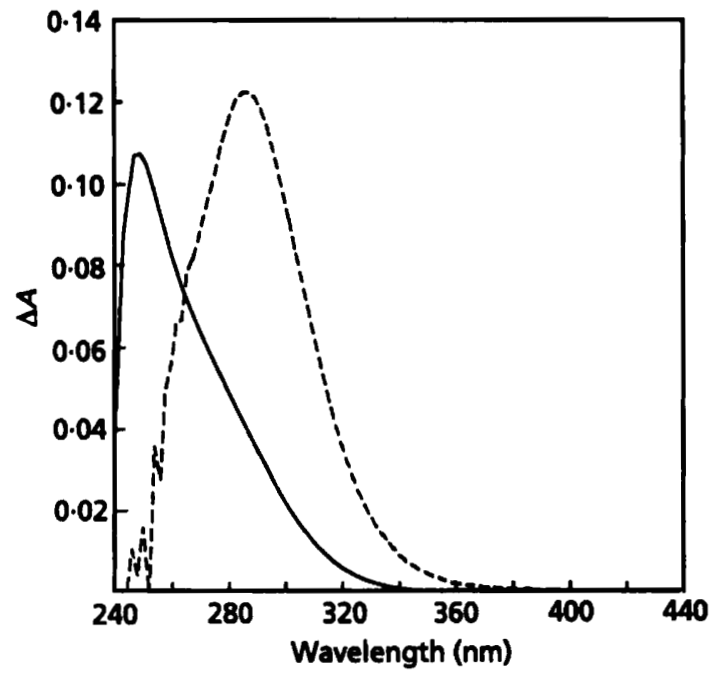

Fig. 3. Initial products formed by tetrathionate hydrolase from tetrathionate and pentathionate. Purified tetrathionate hydrolase $\left(0.2 \mathrm{mg} \mathrm{ml}^{-1}\right)$ was incubated with $1 \mathrm{mM}$ tetrathionate or pentathionate in $1 \mathrm{M}$ ammonium sulfate $(\mathrm{pH} 3)$. Initial products were determined by subtracting the absorbance spectrum at time zero from the absorbance at $2 \mathrm{~min}$. initial product from tetrathionate; ---, initial product from pentathionate.

3), though the final products were the same. Analysis of the final products after pentathionate hydrolysis led to the following reaction scheme:

$\mathrm{S}_{5} \mathrm{O}_{6}^{2-}+\mathrm{H}_{2} \mathrm{O} \rightarrow 2 \mathrm{~S}+\mathrm{S}_{2} \mathrm{O}_{3}^{2-}+\mathrm{SO}_{4}^{2-}+2 \mathrm{H}^{+}$

This shows that twice as much sulfur is produced from pentathionate as from tetrathionate. The rate of penta-

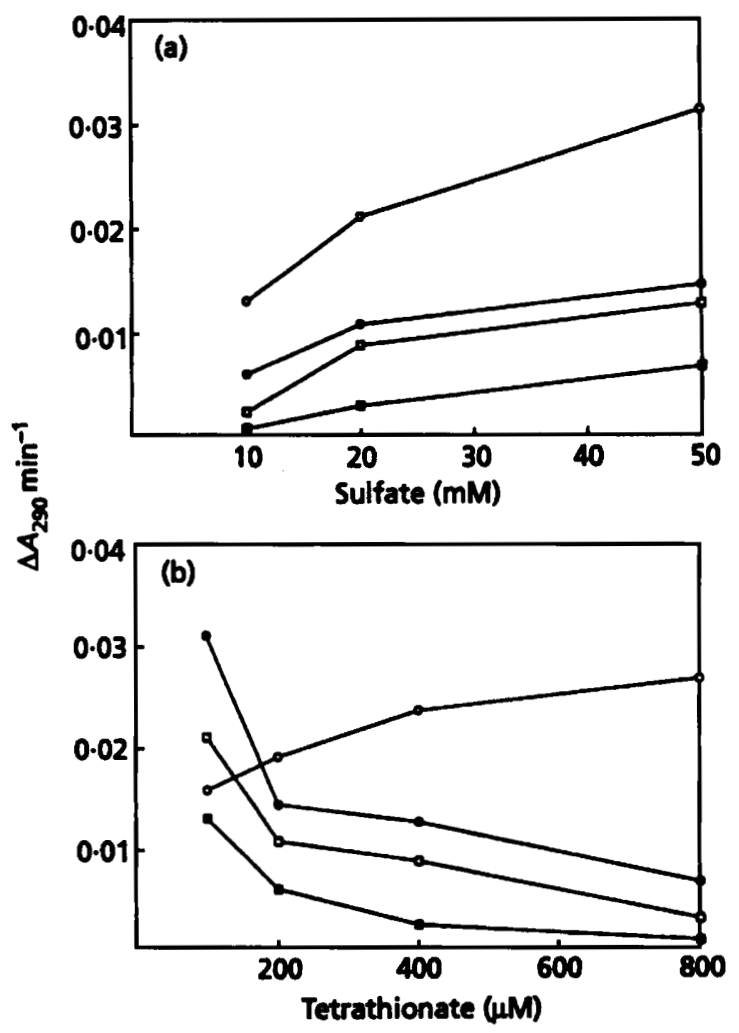

Fig. 4. Effect of ammonium sulfate and tetrathionate on the activity of tetrathionate hydrolase. Stimulation of the hydrolysis of tetrathionate by the tetrathionate hydrolase was investigated at $\mathrm{pH} 3$ at $30^{\circ} \mathrm{C}$. (a) Activity of the tetrathionate hydrolase at varying concentrations of sulfate. Tetrathionate concentration: $\square, 800 \mu \mathrm{M} ; \square, 400 \mu \mathrm{M} ; 0,200 \mu \mathrm{M} ; 0,100 \mu \mathrm{M}$. Sulfate concentrations lower than $10 \mathrm{mM}$ could not be achieved because of the high sulfate concentration in the enzyme sample after gel filtration. (b) Activity of the tetrathionate hydrolase at varying concentrations of tetrathionate. Sulfate concentration: $\square, 10 \mathrm{mM} ; \square, 20 \mathrm{mM}$; $50 \mathrm{mM}$; O, $1000 \mathrm{mM}$. Tetrathionate concentrations below $100 \mu \mathrm{M}$ were not measured because the total change in $A_{290}$ is too low for accurate analysis.

thionate hydrolysis was $80 \%$ of that of tetrathionate hydrolysis. Hydrolysis of hexathionate with tetrathionate hydrolase was not observed, though small $\mathrm{UV} /$ visible changes were observed during incubation of hexathionate with purified enzyme, caused by the contamination of hexathionate with sub-stoichiometric amounts of pentathionate.

\section{Biochemical characterization of tetrathionate hydrolase}

Maximum tetrathionate hydrolysing activity occurred at $\mathrm{pH} 4$. At $\mathrm{pH} 1.5$ and $\mathrm{pH} 7$ the activity had decreased to zero. Tetrathionate hydrolysis increased as the temperature rose from 15 to $65^{\circ} \mathrm{C}$. Above $65^{\circ} \mathrm{C}$, the activity gradually decreased.

The presence of high concentrations of sulfate ions strongly stimulated tetrathionate hydrolysis as is shown in Fig. 4(a). Sulfate could only be replaced by selenate, 
and not by phosphate or chloride. Fig. 4(b) shows the effect of varying tetrathionate and sulfate concentrations on activity. With low concentrations of sulfate, increasing amounts of tetrathionate show inhibition. However, at a concentration of $1 \mathrm{M}$ sulfate, increasing concentrations of tetrathionate show an increase in activity.

The kinetic parameters of tetrathionate hydrolase were determined at $\mathrm{pH} 3$ and $30^{\circ} \mathrm{C}$. The apparent $K_{\mathrm{m}}$ for tetrathionate was $50 \mu \mathrm{M}$ at a concentration of $0.5 \mathrm{M}$ ammonium sulfate.

\section{DISCUSSION}

Tetrathionate hydrolase of $T$. ferrooxidans could relatively easily be separated from other cell components, which was partly due the fact that $50 \%$ of the total protein in the cell-free extract consisted of this enzyme. The enzyme is probably a homodimer. The dependence of the isolation and purification on salt concentration and low $\mathrm{pH}$ have also been observed with the polythionate hydrolases of $T$. acidophilus (Meulenberg $e t$ al., 1992b, 1993b).

The enzyme was only active with tetrathionate and pentathionate, but not with trithionate and hexathionate. Partially purified tetrathionate hydrolase of $T$. acidophilus also showed no activity with trithionate (Meulenberg et al., 1993b).

The $\mathrm{pH}$ optimum for tetrathionate hydrolase activity from $T$. ferrooxidans is about 4 , slightly higher than that reported for the enzyme from T. acidophilus by Meulenberg et al. (1993b). This indicates that the enzyme is probably periplasmic. The strong influence of sulfate on the activity is in agreement with that found for trithionate hydrolase and tetrathionate hydrolase from T. acidophilus (Meulenberg et al., 1992b, 1993b). The competitive effects of sulfate and tetrathionate on enzyme activity were not observed in the latter and are apparently specific to $T$. ferrooxidans. Ammonium sulfate is required for both activity and stability of the enzyme. The temperature optimum is around $65^{\circ} \mathrm{C}$, which is relatively high for an organism with an optimal growth temperature of $30^{\circ} \mathrm{C}$.

An important feature of the purification procedure was the use of the continuous activity assay, making it possible to quickly measure the activities of the fractions after each separation step. This activity measurement is based on the increase of absorbance in the UV region. Though it is clear that the initial step of the hydrolysis reaction is a cleavage between two sulfur atoms, the identity of the first intermediates remains unclear. The instability of the compounds formed may lead to a cascade of reactions ending in the formation of sulfur. The latter can easily be monitored by its precipitation during activity measurements. As can be observed at $430 \mathrm{~nm}$, this happens after a lag period which is probably necessary to form chains long enough to split off a $S_{8}$ molecule.
Recently, we have purified the tetrathionate hydrolase of $T$. acidophilus to homogeneity using the same spectrophotometric assay (unpublished results). However, more detailed spectrophotometric analysis in the $\mathrm{UV} /$ visible region of intermediates formed in the reaction showed substantial differences. The initial hydrolysis of tetrathionate therefore seems to be different, showing that the mechanisms of both enzymes may not be the same. A further analysis of these unstable sulfur intermediates must wait the development of analytical tools to identify and separate these compounds. Tetrathionate hydrolase is present in cell-free extract at concentrations sufficient to explain the rate of thiosulfate and tetrathionate metabolism of $T$. ferrooxidans. Tetrathionate is therefore a main candidate in the oxidative metabolic pathway of thiosulfate to sulfate as proposed by Meulenberg et al. (1992a).

\section{ACKNOWLEDGEMENTS}

We thank Prof. Dr R. Steudel (Department of Inorganic and Analytical Chemistry, University of Technology, Berlin, Germany) for stimulating discussions and providing us with sodium pentathionate. The authors thank Dr L. A. Robertson for critical reading of the manuscript. This project was supported by the EC Programme, Biotechnology of Extremophiles, BIO2-CT93-0274 (DG12 SSMA).

\section{REFERENCES}

Baer, J. E. \& Carmack, M. (1949). The ultraviolet absorption spectra of aliphatic sulfides and polysulfides. J Am Chem Soc 71, 1215-1218.

Hazeu, W., Bijleveld, W., Grotenhuis, J. T. C., Kakes, E. \& Kuenen, J. G. (1986). Kinetics and energetics of reduced sulfur oxidation by chemostat cultures of Thiobacillus ferrooxidans. Antonie Leeuwenboek 52, 507-518.

Hazeu, W., Batenburg-van der Vegte, W. H., Bos, P., van der Pas, R. K. \& Kuenen, J. G. (1988). The production and utilization of intermediary elemental sulfur during the oxidation of reduced sulfur compounds by Thiobacillus ferrooxidans. Arch Microbiol 150, 574-579.

Kelly, D. P. \& Syrett, P. J. (1966). $\left[{ }^{35} S\right]$ Thiosulfate oxidation by Thiobacillus strain C. Biochem J 98, 537-545.

Kelly, D. P., Chambers, L. A. \& Trudinger, P. A. (1969). Cyanolysis and spectrophotometric estimation of trithionate in mixtures with thiosulfate and tetrathionate. Anal Chem 41, 898-901.

Laemmli, U. K. (1970). Cleavage of structural proteins during the assembly of the head of bacteriophage T4. Nature 227, 680-685.

Landesman, J., Duncan, D. W. \& Walden, C. C. (1966). Oxidation of inorganic sulfur compounds by washed cell suspensions of Thiobacillus ferrooxidans. Can J Microbiol 12, 957-964.

Lane, D. J., Harisson, A. P., Stahl, D., Pace, B., Giovannoni, S. J., Olsen, G. \& Pace, N. R. (1992). Evolutionary relationships among sulfur- and iron-oxidizing Eubacteria. J Bacteriol 174, 269-278.

London, J. \& Rittenberg, S. C. (1964). Path of sulfur in sulfide and thiosulfate oxidation by Thiobacilli. Proc Natl Acad Sci USA 52, 1183-1190.

Lu, W.-P. \& Kelly, D. P. (1988). Kinetic and energetic aspects of 
inorganic sulphur compound oxidation by Thiobacillus tepidarius. J Gen Microbiol 134, 865-876.

Meulenberg, R., Pronk, J. T., Hazeu, W., Bos, P. \& Kuenen, J. G. (1992a). Oxidation of reduced sulphur compounds by intact cells of Thiobacillus acidophilus. Arch Microbiol 157, 161-168.

Meulenberg, R., Pronk, J. T., Frank, J., Hazeu, W., Bos, P. \& Kuenen, J. G. (1992b). Purification and partial characterization of a thermostable trithionate hydrolase from the acidophilic sulphur oxidizer Thiobacillus acidophilus. Eur J Biochem 209, 367-374.

Meulenberg, R., Pronk J. T., Hazeu, W., van Dijken, J. P., Frank, J., Bos, P. \& Kuenen, J. G. (1993a). Purification and partial characterization of thiosulphate dehydrogenase from Thiobacillus acidophilus. J Gen Microbiol 139, 2033-2039.

Meulenberg, R., Scheer, E. J., Pronk, J. T., Hazeu, W., Bos, P. \& Kuenen, J. G. (1993b). Metabolism of tetrathionate in Thiobacillus acidophilus. FEMS Microbiol Lett 112, 167-172.

Okuzumi, M. (1965). Studies on biochemistry of the Thiobacilli. Part VII. Metabolism of tetrathionate by T. thiooxidans. Agric Biol Chem 29, 1069-1073.

Okuzumi, M. (1966). Studies on biochemistry of the Thiobacilli. Part VIII. Dismutation of tetrathionate by T. thiooxidans. Agric Biol Chem 30, 313-318.

Okuzumi, M. \& Kita, Y. (1965). Studies on biochemistry of the Thiobacilli. Part VI. Oxidation of thiosulfate to tetrathionate by T. thiooxidans. Agric Biol Chem 29, 1063-1068.

Parker, C. D. \& Prisk, J. (1953). The oxidation of inorganic compounds of sulphur by various sulphur bacteria. J Gen Microbiol 8, 344-364.

Pronk, J. T., Meulenberg, R., Hazeu, W., Bos, P. \& Kuenen, J. G. (1990). Oxidation of reduced inorganic sulphur compounds by acidophilic thiobacilli. FEMS Microbiol Rev 75, 293-309.

Sinha, A. B. \& Walden, C. C. (1966). Formation of polythionates and their interrelationships during oxidation of thiosulphate by Thiobacillus ferrooxidans. Can J Microbiol 12, 1041-1054.

Sklodowska, A. (1988). Polythionates and adenosine-5-phosphosulfate formation during thiosulfate oxidation by Thiobacillus neapolitanus. Can J Microbiol 34, 1283-1287.
Starkey, R. L. (1935). Products of the oxidation of thiosulfate by bacteria in mineral media. J Gen Physiol 18, 325-349.

Steudel, R. (1989). On the nature of the 'elemental sulfur' $\left(S^{\circ}\right)$ produced by sulfur-oxidizing bacteria - a model for $\mathrm{S}^{\circ}$ globules. In Autotrophic Bacteria, pp. 289-303. Edited by H. G. Schlegel \& S. Bowien. Madison, USA: Science Tech Publishers.

Steudel, R., Holdt, G., Gobbel, T. \& Hazeu, W. (1987). Chromatographic separation of higher polythionates $\mathrm{S}_{n} \mathrm{O}_{6}^{2-}(n=3 \ldots 22)$ and their detection in cultures of Thiobacillus ferrooxidans; molecular composition of bacterial sulfur secretions. Angew Chem Int Ed Engl 26, 151-153.

Steudel, R., Gobbel, T. \& Holdt, G. (1988). The molecular composition of hydrolytic sulfur sols prepared by acid decomposition of thiosulfate. $Z$ Naturforsch 43b, 203-218.

Trudinger, P. A. (1964a). Evidence for a four-sulphur intermediate in thiosulfate oxidation by Thiobacillus X. Aust J Biol Sci 17, 577-579.

Trudinger, P. A. (1964b). The metabolism of trithionate by Thiobacillus X. Aust J Biol Sci 17, 459-468.

Trudinger, P. A. (1964c). Products of anaerobic metabolism of tetrathionate by Thiobacillus X. Aust J Biol Sci 17, 446-458.

Trudinger, P. A. (1965). Effect of thiol-binding reagents on the metabolism of thiosulfate and tetrathionate. J Bacteriol 89, $617-625$.

Van lersel, J., Frank Jzn, J. \& Duine, J. A. (1985). Determination of absorption coefficients of purified proteins by conventional ultraviolet spectrophotometry and chromatography combined with multiwavelength detection. Anal Biochem 151, 196-204.

Vishniac, W. (1952). The metabolism of Thiobacillus thioparus. I. The oxidation of thiosulfate. J Bacteriol 64, 363-373.

Wood, A. P. \& Kelly, D. P. (1986). Chemolithotrophic metabolism of the newly-isolated moderately thermophilic, obligately autotrophic Thiobacillus tepidarius. Arch Microbiol 144, 71-77.

Received 2 July 1996; revised 10 September 1996; accepted 18 September 1996. 